УДК 351:614

DOI: https://doi.org/10.32689/2618-0065-2018-1/1-67-78

Майстро Сергій Вікторович доктор наук 3 державного управління, професор, завідувач кафедри публічного адміністрування у сфері цивільного захисту Національного університету цивільного захисту, м. Харків, вул. Баварська, 7, 61000, Україна тел.: (057)-704-14-50, e-mail: nuczu@dsns.gov.ua

ORCID: 0000-0003-3035-4304

\title{
СПЕЦИФІКА ФОРМУВАННЯ СИСТЕМИ ДЕРЖАВНОГО УПРАВЛІННЯ ПРИРОДНО-ТЕХНОГЕННОЮ БЕЗПЕКОЮ
}

Анотація. Проблема захисту населення та територій від катастроф різного спрямування $\epsilon$ дуже актуальною і стосується фундаментальних основ економічної безпеки. На початку XXI ст. глобальні загрози стали вже комплексними, який проявляється $\mathrm{y}$ : взаємозалежності природних, техногенних, політичних, економічних, соціальних, екологічних і науково-технічних ризиків; у масштабах надзвичайних ситуацій; у загостренні старих і появу нових нетрадиційних видів небезпек. Комплексність сучасних загроз обумовила пошук такого шляху цивілізаційного розвитку, який, не руйнуючи своєї природної основи, забезпечує людству можливість виживання і подальшого безперервного розвитку. Важливою особливістю концепції сталого розвитку $є$ те, що в ній проблема цивілізаційного розвитку тісно переплітається 3 проблемою формування систем безпеки як на глобальному, так і на національному рівнях. Як правило, важливі державні рішення певних сферах суспільного життя приймаються без урахування необхідності забезпеченн безпеки і в інших сферах. Така ситуація обумовлена, насамперед неадекватним уявленням про роль та місце останніх у процесах розвитку. У статті обгрунтовано необхідність формування ефективної системи державного управління природно-техногенною безпекою та визначено ii цілі. Проаналізовано основні принципи формування й ефективного функціонування системи державного управління природно-техногенною безпекою в умовах надзвичайних ситуацій. В дослідженні визначено, що метою функціонування СУ ПТБ є попередження природно-техногенних катастроф i аварій, своєчасне прийняття заходів щодо локалізації і ліквідації наслідків НС природного i техногенного характеру, раціональне використання ресурсів системи для забезпечення ПТБ.

Обгрунтовано, що ЕТС це певним чином організовані соціум, об'єкти економіки, техносфери, а також природно-територіальні екосистеми, які 
утворюють єдине структурно-функціональне ціле. Структурні підсистеми за своїми просторовими і іншими параметрами відповідають адміністративногосподарським територіальним утворенням та можуть бути різного рівня i масштабу - від національного до об’єктового.

Ключові слова: природно-техногенна безпека, управління, ризик, надзвичайна ситуація.

Maystro Sergey Victorovich Doctor of Sciences in Public Administration, Professor, Head of the Department of Public Administration in the field of Civil Protection of the National University of Civil Defense, Kharkiv, ul. Bavaria, 7, 61000, Ukraine tel .: (057) -704-14-50, e-mail: nuczu@dsns.gov.ua

ORCID: 0000-0003-3035-4304

\section{SPECIFICATION OF THE FORMATION OF THE SYSTEM OF PUBLIC MANAGEMENT BY NATURAL TECHNOLOGICAL SAFETY}

Annotation. The problem of protecting people and territories from disasters of different directions is very relevant and concerns the fundamental foundations of economic security. At the beginning of the XXI century. global threats have already become complex, which manifests itself in: the interdependence of natural, man-made, political, economic, social, environmental and scientific and technical risks; in emergency situations; in exacerbating the old and the emergence of new non-traditional types of hazards. Complexity of modern threats has led to the search for such a way of civilization development, which, without destroying its natural basis, provides humanity with the possibility of survival and further continuous development. An important feature of the concept of sustainable development is that in it the problem of civilization development is closely intertwined with the problem of the formation of security systems, both globally and nationally. As a rule, important public decisions in certain spheres of public life are taken without regard to the need for security in other areas. This situation is due, first of all, to inadequate understanding of the role and place of the latter in the development process. The article substantiates the necessity of forming an effective system of state management of natural and man-made safety and defines its goals. The basic principles of formation and effective functioning of the system of state management of natural and technological safety in the conditions of emergency situations are analyzed. The study determined that the purpose of the operation of the SU of the PTB is to prevent natural and man-made disasters and accidents, timely 
adoption of measures for the localization and liquidation of the consequences of natural and man-made disasters, and the rational use of the resources of the system for the provision of the PTB.

It is substantiated that the ecologically-technogenic system is a certain way organized society, objects of the economy, technosphere, as well as natural-territorial ecosystems that form a single structural and functional whole. Structural subsystems according to their spatial and other parameters correspond to administrative-economic territorial formations and can be of different levels and scales - from national to object.

Key words: natural and man-made safety, management, risk, emergency situation.

Постановка проблеми. На сучасному етапі суспільного розвитку небезпека природних і техногенних, соціальних ризиків стала співрозмірна 3 воєнними загрозами. Аналіз тенденцій збільшення соціально-економічних збитків від надзвичайних ситуацій (далі - НС) природного і техногенного спрямування засвідчує необхідність формування ефективної системи управління природнотехногенною безпекою (далі - СУ ПТБ), функціонування якої повинно бути спрямоване на розробку заходів забезпечення високого рівня природнотехногенної безпеки.

Аналіз останніх досліджень і публікацій. Суттєвий внесок у дослідження проблеми сталого розвитку та забезпечення прийнятного рівня природнотехногенної безпеки зробили українські вчені: О. Ф. Балацький, В. А. Боков, О. І. Відоменко, В. О. Волошин, С. М. Волошин, Б. М. Данилишин, Б. В. Дзюндзюк, С. І. Дорогунцов, А. Б. Качинський, В. В. Ковтун, С. М. Козьменко, О. Ю. Кононенко, Є. С. Лавейкіна, В. С. Луцько, В. А. Одинець, І. М. Підкамінний, О. М. Ральчук, А. В. Степаненко, А. М. Федорищева, С. В. Хлобистов, В. Б. Швед, В. Я. Шевчук та ін.

Формулювання цілей статmі. Метою статті $\epsilon$ дослідити специфіку формування системи державного управління природно-техногенною безпекою.

Виклад основного матеріалу дослідження. Природний і техногенний ризик $\epsilon$ факторами, які досить часто визначають якість життя населення країни. Рівень природного і техногенного ризику, якому піддається людина, залежить від трьох чинників: ймовірності виникнення НС, їх масштабів і рівня захищеності, що забезпечується відповідними службами. Проблема зниження сукупного соціально-економічного ризику, особливості роботи в умовах НС спричиняють велику кількість завдань фундаментального та прикладного наукового спрямування. Насамперед, це завдання створення ефективної системи планування та оперативного управління комплексами заходів із попередження і ліквідації НС [1 - 7]. 
Тому вдосконалення систем управління, орієнтованих на прогноз i попередження НC, на захист населення i територій, має особливо велике значення.

Формування СУ ПТБ повинно базуватись на двох положення:

- правильного встановлення кінцевої мети;

- відшукання відповідних коштів, які забезпечують відповідний рівень ПТБ.

При визначенні принципів формування СУПТБ треба враховувати, що управління - це процес, до якого належать:

- вироблення альтернативних керуючих впливів;

- прийняття рішення про вибір із них найефективніших;

- здійснень керуючих впливів 3 метою досягнення бажаних результатів функціонування керованого об’єкта [8].

Доцільність вибору ЕТС як об’єкта дослідження проблем безпеки природноантропогенних систем, на нашу думку, обумовлена такими чинниками:

a) ця система включає джерело небезпеки (екологічна, техногенна i соціальна підсистема) і потенційну жертву (об’єкт і суб’єкт небезпеки);

б) функціонування ЕТС адекватно відображає реальні природні i соціально-економічні процеси;

в) модель ЕТС дає змогу використовувати при аналізі небезпек загальносистемні принципи, що дає змогу певною мірою прогнозувати появу небезпечних ситуацій.

За допомогою аналізу структури і типу природних та техногенних загроз можна виокремити найбільш загальні принципи формування системи управління безпеки. Ми будемо трактувати СУ ПТБ як сукупність нормативних актів, організаційно-технологічних заходів і ресурсів, які забезпечують нормальне функціонування ЕТС і мінімізацію наслідків реалізації небезпечних природнотехногенних процесів.

Найважливіше завдання управління СУ ПТБ - врахування інтересів особи, суспільства і держави в цій сфері. Інтереси особи в сфері ПТБ полягають у реалізації конституційних прав людини і громадянина на доступ до інформації, забезпечення фізичного, духовного та інтелектуального розвитку, а також доступ до інформації, що забезпечує особисту безпеку. Дотримання принципу балансу інтересів громадян, суспільства і держави передбачає законодавче закріплення пріоритету цих інтересів у різних сферах життєдіяльності суспільства, а також використання різних форм громадського контролю над діяльністю органів державної влади та органів державної влади регіональних суб'єктів щодо організації системи ПТБ. 
Важливою метою функціонування СУ ПТБ $є$ попередження природнотехногенних катастроф i аварій, своєчасне прийняття заходів щодо локалізації $\mathrm{i}$ ліквідації наслідків НС природного і техногенного характеру, раціональне використання ресурсів системи для забезпечення ПТБ.

Специфікою СУ ПТБ є те, що непередбачуваність реалізації надзвичайних ситуацій змушує прогнозувати наслідки управлінських рішень на більше число «ходів» вперед, діяти швидко і точно. Це призводить до необхідності розробки різних варіантів управлінських рішень та пошуку серед них різних найкращих. При цьому керівникам доводиться приймати оперативні рішення у досить невизначених умовах і за досить обмежений час. Це може призвести до прийняття нераціональних і навіть помилкових рішень, тобто до великих втрат.

Аналіз функціонування систем управління в умовах НС дав змогу виділити декілька їх особливостей у порівнянні $з$ традиційними системами управління (табл. 1).

Таблиця 1

Порівняльна характеристика системи управління

\begin{tabular}{|c|c|}
\hline Традиційні системи управління & Системи управління в умовах НС \\
\hline Постійний режим функціонування & Різні режими функціонування \\
\hline $\begin{array}{l}\text { Жорстка структура і чіткий розподіл функцій на } \\
\text { тривалий період }\end{array}$ & $\begin{array}{l}\text { Відсутність жорсткої структури і чіткого розподілу } \\
\text { функцій на тривалий період, гнучкість, агресивність }\end{array}$ \\
\hline Вузька функціональна спрямованість & Широка і частково непередбачувана область дії \\
\hline Моноструктура & Поліструктури \\
\hline Регламентовані інформаційні потоки & $\begin{array}{l}\text { Залежність інформаційних потоків від складності } \\
\text { ситуації }\end{array}$ \\
\hline Точна інформація & Недостовірна інформація \\
\hline Надмірний обсяг інформації & Недостатній обсяг інформації \\
\hline Невисокий темп змін & Високий темп змін \\
\hline Передбачуваність ситуацій & $\begin{array}{l}\text { Непередбачуваність ситуації; орієнтація на минулий } \\
\text { досвід, як правило, не має сенсу }\end{array}$ \\
\hline $\begin{array}{ll}\text { Принцип єдності } & \text { повноважень } \\
\text { відповідальності } & \end{array}$ & $\begin{array}{l}\text { Поєднання принципів єдиноначальності, розподілених } \\
\text { повноважень та відповідальності }\end{array}$ \\
\hline Функціональний потенціал & Організаційний потенціал \\
\hline $\begin{array}{l}\text { Переважання } \quad \text { здебільшого } \\
\text { економічних цілей і критеріїв функціонування }\end{array}$ & $\begin{array}{l}\text { Цілі: дієвість, результативність у ліквідації НС та їх } \\
\text { причин; критерії мінімізація часу досягнення цілей, } \\
\text { мінімум втрат (жертв) при ліквідації НС }\end{array}$ \\
\hline
\end{tabular}

Загалом, функції держави стосовно управління ПТБ полягають у наступному:

- здійснення об'єктивного і всебічного аналізу та прогнозування природнотехногенних загроз;

- організація робіт органів влади щодо реалізації комплексу заходів, спрямованих на запобігання і нейтралізацію загроз ПТБ; 
- підтримка діяльності громадських об’єднань, спрямована на об’єктивне інформування населення щодо проблем ПТБ, надання фізичним і юридичним особам доступу до інформаційних ресурсів, глобальних інформаційних мереж;

- організація розробки державної програми забезпечення ПТБ, яка об’єднує зусилля державних і недержавних організацій в зазначеній області.

Суттєва специфіка СУ ПТБ полягає у тому, що вона може функціонувати в таких режимах:

- повсякденної діяльності;

- підвищеної готовності;

- надзвичайної ситуації.

Режим повсякденної діяльності характеризується відсутністю інформації про явні ознаки загрози виникнення НС і головним завданням стає попереджувальне планування, основною метою якого є:

- збір інформації для прогнозування можливих НC;

- накопичення ресурсів, необхідних для ліквідації наслідків НС;

- розробка сценаріїв дій у разі виникнення НС, які дають змогу ефективно реагувати на очікувані проблеми;

- паспортизація безпеки.

У цьому режимі визначаються і створюються законодавчі, нормативні i економічні механізми, спрямовані на мінімізацію ризику та збитків від НС.

Система керування ПТБ загалом об’єднує три підсистеми: правову; організаційно- технічну і економічну. Правова підсистема охоплює розробку нормативних правових актів, що регламентують відносини в сфері ПТБ, і нормативних методичних документів із питань забезпечення безпеки України. Організаційно-технічна підсистема управління забезпечення ПТБ спрямована на створення та вдосконалення систем забезпечення безпеки; посилення правової бази діяльності органів влади, включаючи попередження i припинення правопорушень в сфері ПТБ. До економічних методів забезпечення інформаційної безпеки належать:

- розробка економічних програм забезпечення ПТБ та визначення порядку їх фінансування;

- вдосконалення системи фінансування робіт, пов'язаних із реалізацією правових i організаційно-технічних методів захисту інформації, створення системи страхування природних та техногенних ризиків фізичних і юридичних осіб.

Важливість економічної підсистеми полягає у тому, що набір економічних заходів, що потребують значних коштів, спрямованих на попередження лих $\mathrm{i}$ катастроф, як правило, досить обмежений - на сьогодні на попередження багатьох 
загроз витрачається в десятки і сотні разів менше, ніж вимагає ліквідація їх наслідків. Водночас ці витрати дають змогу значно зменшити економічний збиток від лих загалом.

Аналіз стану ПТБ в Україні засвідчує, що иї рівень не повною мірою відповідає вимогам часу. Все ще існує низка проблем, які серйозно перешкоджають повноцінному забезпеченню безпеки людини, суспільства i держави. До найбільш загальних належать:

- сучасні умови соціально-економічного розвитку країни не дозволяють повною мірою забезпечити потреби у безпеці як для людини зокрема, так i суспільства загалом;

- суперечливість і нерозвиненість правового регулювання суспільних відносин у сфері безпеки істотно утрудняє підтримку необхідного балансу інтересів особистості, суспільства і держави в цій галузі;

- незабезпеченість прав громадян на доступ до інформації 3 безпеки, маніпулювання інформацією викликають негативну реакцію населення, що в деяких випадках призводить до дестабілізації соціально-політичної обстановки в суспільстві;

- відсутня конкретність при проведенні єдиної політики в галузі формування державної системи безпеки, іiї зв’язків із міжнародною системою безпеки, що значно понижує ефективність функціонування національної системи безпеки загалом;

- незабезпеченість кадровим потенціалом наукових і виробничих колективів, що діють в області створення систем безпеки, значний відхід із цих колективів найбільш кваліфікованих фахівців;

- недостатній рівень вітчизняних технологій забезпечення ПТБ змушує органи державної влади та органи місцевого самоврядування при створенні систем безпеки йти шляхом закупівель імпортної техніки і залучення іноземних фірм. Через це зростає залежність від іноземних виробників техніки, що утруднює формування ефективних систем безпеки.

Специфікою СУ ПТБ є те, що на відміну від ринкової економіки, командноадміністративні методи керування, дотримання принципу особистої відповідальності на об’єктах, що представляють небезпеку для життя і здоров’я людей, є необхідним і ефективним елементом управління в умовах використання небезпечних технологій та в умовах дефіциту часу.

СУ ПТБ вимагає розробки науково обгрунтованої стратегії, яка повинна включати такі основні моменти:

- розробку єдиного підходу до класифікації ризиків;

- організацію відділів із управління ризиком на підприємствах; 
- створення і впровадження методики реєстрації збитків у матеріальному та економічному виразі;

- створення і впровадження методики прогнозування аварійних ситуацій, оцінки можливих наслідків;

- формування глобальної бази даних щодо збитків у межах окремих об’єктів та цілої галузі;

- розробку методики оцінки порівняння ефективності різних заходів із управління ПТБ та рекомендацій щодо їх використання в конкретних випадках;

- активне використання страхування і самострахування.

Серед моделей СУ ПТБ переважають економічні моделі управління безпекою територіально-виробничих комплексів. Мета цих моделей - оцінити небезпеку існуючих об’єктів, розробити заходи щодо попередження аварій i катастроф i визначити систему пріоритетів. При цьому моделі повинні давати оцінки можливого збитку, якщо ті чи інші заходи прийняті не будуть. Робота над проектом програми за прогнозом та попередження аварій, катастроф і стихійних лих та пом'якшення їх наслідків свідчить про незадовільний стан справ у частині, що стосується пріоритетів. Досить часто термінові, першочергові проекти не відділяються від другорядних, що не дозволяє ефективно використовувати наявні фінансові ресурси.

Зарубіжна та вітчизняна практика засвідчує, що навіть достовірної та чіткої інформації часто виявляється недостатньо для того, щоб керівництво негайно відреагувало на НС, вдавшись до адекватних оперативних заходів у відповідь.

Функціонування СУ ПТБ в умовах НС характеризується низкою особливостей.

Небезпека. Ї̈ї ступінь в умовах НС може бути різним (від безпосередньої небезпеки для життя до найлегших форм хвороби). Емоційний вплив небезпечних факторів на людину визначається не тільки їх об’єктивним рівнем, але і власним уявленням людини про те, яку загрозу це несе їй.

Дефiüum часу. Більшість робіт в умовах НС необхідно виконувати або в мінімальний, або в строго визначений термін. Дефіцит часу складається 3 трьох основних складових: реально існуючий дефіцит, що залежить від ситуації; дефіцит, пов’язаний з термінами перебування співробітників («ліміт безпеки») в зоні НC і зміною команд (додатковий час на адаптацію, ознайомлення з ситуацією тощо); дефіцит, обумовлений особливостями психологічного стану і підготовки співробітників.

Особливості виконуваної роботи $i$ ï організації. При ліквідації НС доводиться виконувати величезний обсяг фізичної та інтелектуальної роботи, як правило, нетипової. Далеко не завжди зрозуміло, що потрібно робити. Але навіть 
якщо зрозуміло, що потрібно робити, не завжди існує чітке уявлення, як і яким чином це робити. Способи вирішення проблем, що виникають, часто визначаються методом проб і помилок. При цьому швидко й інколи не обгрунтовано змінюються поставлені завдання і вимоги для їх вирішення. Досить часто робота ускладнюється негативними емоціями від безплідно витрачених зусиль і нераціональних управлінських рішень.

Відносна ізоляція. Особи, які беруть участь у ліквідації НC, упродовж тривалого періоду знаходяться у певній ізоляції. Негативний вплив ізоляції посилюється відривом від звичної системи трудових і соціальних відносин, необхідністю підпорядкування новій системі вимог, обмеженням свободи переміщення і досить жорсткими регламентаціями поведінки.

Biдповідальність. Як правило, роботи з ліквідації НС знаходяться в центрі суспільної уваги. Участь у таких роботах сприймається, з одного боку, як справа честі і предмет гордості, а з іншого - як джерело небезпеки й ризику для здоров'я. Тому участь у роботах із ліквідації $\mathrm{HC}$ не повинна бути примусовим обов'язком. Вона повинна розглядатися як відповідальне доручення, яке не можна виконати недобросовісно, адже ціна неякісного виконання завдань дуже висока.

Серйозною проблемою організації ефективного управління в умовах $\mathrm{HC} \epsilon$ відсутність координації діяльності офіційних урядових, відомчих і неурядових органів. Часто виникає плутанина при вирішенні питання, чим має займатися певна установа. Це призводить до дублювання роботи в одних областях i бездіяльності в інших. Проте традиційні підходи до управління в умовах НС, як показує досвід їх використання, призводять до незадовільних результатів.

При складній i мінливій структурі оточуючого середовища система управління насамперед повинна бути гнучкою і адаптивної. Вона повинна бути пристосована до визначення нових проблем та вироблення нових рішень більшою мірою, ніж до контролю вже прийнятих рішень та їх реалізації. У них повинна бути забезпечена можливість максимальної концентрації ресурсів, об'єднання інформаційних, організаційних та інших типів ресурсів для ліквідації наслідків НС у найкоротші терміни.

Для СУ ПТБ характерним $є$ поєднання двох, в звичайних умовах взаємовиключних), принципів: єдиноначальність (єдність повноважень і відповідальності) та розподіл повноважень і відповідальності. 3 одного боку, керівник несе персональну відповідальність за стан справ, з іншого - у роботі центру, в якому вирішуються питання взаємодії і координації між керівниками різних рівнів та зон розвитку $\mathrm{HC}$, реалізується принцип розподіленої відповідальності. У центрі створюються умови для необхідних погоджень і консультацій для усунення неминучих конфліктів та розбіжностей. Це забезпечує 
мінімальне втручання перших осіб в оперативну діяльність керівників нижчих рівнів.

Організаційна структура СУ ПТБ в умовах НС повинна бути 3 локальною автономією і глобальної координацією. Ї̈̈ різні елементи беруть участь у встановленні цілей і завдань та спільними зусиллями домагаються їх реалізації.

Поєднання аналізу основ комплексного цільового управління з вивченням практики функціонування систем управління ПТБ дає змогу сформулювати низку принципів побудови систем планування і управління з попередження та ліквідації НС на регіональному рівні.

До таких принципів належать:

- орієнтація на конкретно існуючі організаційну і функціональну структури системи управління регіоном;

- комплексність планів соціального розвитку і забезпечення ПТБ;

- альтернативність формування планів і виділення базових варіантів, орієнтованих на найбільш вірогідний, сприятливий та несприятливий сценарій розвитку ситуації;

- раціональне поєднання процесів формування планів “знизу” i “зверху” шляхом залучення до розробки планів низових структур і приватного сектора (цей принцип реалізується насамперед шляхом широкого залучення підприємств i організацій для складання адекватних паспортів ПТБ та їх подальшого узагальнення на регіональному рівні, формування сценаріїв розвитку НC i відповідних дій тощо);

- відповідальність виконавців та керівників за коректність сценаріїв, планів і якість прийнятих управлінських рішень та їх реалізацію;

- збалансованість планів (передбачається ресурсне забезпечення реалізації планів: кадрове, матеріально-технічне, фінансове, інформаційне тощо);

- оптимальність i адаптивність (передбачається можливість вибору ефективного варіанту збалансованого плану і його пристосованість до реальних умов);

- типізація змісту та процедур формування сценаріїв, превентивних i оперативних планів з попередження й ліквідації НС (типізація при цьому означає зведення всього різноманіття сценаріїв, планів, керуючих і контролюючих впливів до досить обмеженої кількості, що ефективно задовольняє вимоги превентивного планування та оперативного управління);

- безперервність і модифікація - процес планування повинен бути ковзаючим, тобто в кожен момент часу розглядається реалізована частина планів і готується основа для прийняття планів на майбутній період; 
- орієнтація оперативних планів протидії розвитку НС на першочергове використання місцевих і об’єктових ресурсів, сил та засобів;

- синергізм - взаємне посилення планованих заходів.

Висновки. Узагальнюючи, можна констатувати, що на сучасному етапі цивілізаційного розвитку проблеми безпеки стають проблемами виживання соціуму. НС природно- техногенного спрямування стають постійними і все більш важливою частиною соціального розвитку. Для України винятково важливим $\epsilon$ прийняття концепції управління ПТБ, яка повинна відображати вибір суспільства і визначати головні напрямки досягнення високого рівня природно-техногенної безпеки.

\section{Jimepamypa:}

1. Биченок М. М. Основи інформатизації управління регіональною безпекою : монографія. Київ : РНБОУ, 2005. 196 с.

2. Дорогунцов С. И., Ральчук А. Н. Управление техногенно-экологической безопасностью в контексте парадигмы устойчивого развития: концепция системнодинамического решения : монография. Киев : Наукова думка, 2002. 200 с.

3. Измалков А. В. Управление безопасностью социально-экономических систем и оценка его эффективности : научное пособие. Москва : Компания Спутник+, 2003. 441 с.

4. Безопасность Европы / под ред. В. В. Журкина. Москва : Весь Мир, 2011. 752 с.

5. Болтыров В. Б. Опасные природные процессы : учеб. пособ. Москва : Книжный дом «Университет», 2010. $588 \mathrm{c}$.

6. Медоуз Д. Х. Азбука системного мышления : науч. пособие. Москва : БИНОМ. Лаборатория знаний, 2010. $343 \mathrm{c}$.

7. Медоуз Д. Х. Пределы роста: 30 лет спустя : науч. пособие. Москва : БИНОМ. Лаборатория знаний, 2012. $358 \mathrm{c}$.

8. $\quad$ Теория управления. Терминология : монография. Москва : Наука, 1988. Вып. 107. $56 \mathrm{c}$.

\section{References:}

1. $\quad$ Bychenok, M. M. (2005). Osnovy informatyzatsii upravlinnia rehionalnoiu bezpekoiu [Fundamentals of Informatization of Regional Security Management]. Kyiv: RNBOU [in Ukrainian].

2. Doroguntsov, S. I., Ralchuk, A. N. (2002). Upravlenie tekhnogenno-ekologicheskoy bezopasnostyu $v$ kontekste paradigmy ustoychivogo razvitiya: kontseptsiya sistemno-dinamicheskogo resheniya [Managing Technogenic-Ecological Safety in the Context of the Sustainable Development Paradigm: The Concept of a System-Dynamic Solution]. Kiev: Naukova dumka [in Russian].

3. Izmalkov, A. V. (2003). Upravlenie bezopasnostyu sotsialno-ekonomicheskikh sistem i otsenka ego effektivnosti [Security management of socio-economic systems and evaluation of its effectiveness]. Moscow: Kompaniya Sputnik+ [in Russian].

4. Zhurkin, V. V. (Eds.). (2011). Bezopasnost Evropy [European Security]. Moscow: Ves Mir [in Russian].

5. Boltyrov, V. B. (2010). Opasnye prirodnye protsessy [Dangerous natural processes]. Moscow: Knizhnyy dom «Universitet» [in Russian]. 
6. Medouz, D. Kh. (2010). Azbuka sistemnogo myshleniya [The ABC of Systems Thinking]. Moscow: BINOM. Laboratoriya znaniy, [in Russian].

7. Medouz, D. Kh. (2012). Predely rosta: 30 let spustya [Limits of growth: 30 years later]. Moscow: BINOM. Laboratoriya znaniy [in Russian].

8. Teoriya upravleniya. Terminologiya [Management Theory. Terminology]. (1988). Moscow: Nauka [in Russian]. 